\title{
Exchange Rate Regime and Wage Determination in Central and Eastern Europe
}

\author{
GUNTHER SCHNABL \\ CHRISTINA ZIEGLER
}

\author{
CESIFO WORKING PAPER NO. 2471 \\ CATEgORY 6: MONETARY POLICY AND INTERNATIONAL FinanCE \\ NOVEMBER 2008
}
An electronic version of the paper may be downloaded
- from the SSRN website: Www.SSRN.com
- from the RePEc website: $\quad$ www.RePEc.org
- from the CESifo website: www.CESifo-group.org/wp




\title{
Exchange Rate Regime and Wage Determination in Central and Eastern Europe
}

\begin{abstract}
After the eastern enlargement of the European Union due to increasing labor market integration, wage determination and monetary integration in Central and Eastern Europe have become key issues in European economic policy making. Based on the Scandinavian model of wage adjustment by Lindbeck (1979), we intend to analyze the role of exchange rates in the wage determination process of the Central and Eastern European countries to identify which exchange rate strategy contributes to faster wage convergence in Europe. Panel estimations reveal a robust negative relationship between exchange rates and wage growth. This suggests that workers in countries with fixed exchange rates are likely to benefit from higher wage increases.
\end{abstract}

JEL Code: C23, J30, F31, O52.

Keywords: wage policy, labor markets, exchange rate regime, Central and Eastern Europe.

\author{
Gunther Schnabl \\ Leipzig University \\ Marschnerstrasse 31 \\ 04109 Leipzig \\ Germany \\ schnabl@wifa.uni-leipzig.de
}

\author{
Christina Ziegler \\ Leipzig University \\ Marschnerstrasse 31 \\ 04109 Leipzig \\ Germany \\ ziegler@wifa.uni-leipzig.de
}

The authors thank Robinson Kruse, Christian Danne, Andreas Hoffmann, Renate Ohr, Holger Zemanek, the participants of the workshop "Internationale Wirtschaftsbeziehungen" in Göttingen and of the Ph.D. seminar in Leipzig for inspiring discussion and helpful comments. 


\section{Introduction}

Choosing the appropriate exchange rate regime remains an important and controversial economic policy issue for the Central and Eastern European countries (Belke and Kaas 2004, von Hagen and Zhou 2005, Fidrmuc and Korhonen 2006, Schnabl 2008). Although exchange rate stability in CEE has grown since the introduction of the euro different exchange rate strategies persist. While Estonia, Lithuania, Latvia, Bulgaria, Slovenia and the Slovak Republic are pegging their currencies tightly to the euro or have chosen to join the euro area, the Czech Republic, Poland and most recently Hungary allow their exchange rates to be widely determined by market forces. The central bank of Romania manages the exchange rate discretionarily.

At the same time wage determination in Central and Eastern Europe (CEE) has become a key issue in European economic policy making, as large differences in wage levels persist (ECOFIN 2005, European Commission 2007). For instance, labor unions in CEE have tended to claim substantial wage increases to achieve a faster wage convergence to the EU15 (see for instance the Skoda wage bargaining process in the Czech Republic 2007). These claims have been accentuated by the fact that rising production, increasing productivity and labor migration to Western Europe have led to a shortage of (highly-qualified) workers (Goretti 2008). Nonetheless, institutional factors such as the different tax systems, wage rigidities, a low degree of both unionization and collective bargaining have contributed to the persistence of wage gaps (EIRO 2008).

Although both, the choice of exchange rate regime and the wage determination process in Central and Eastern Europe have been subject to extensive academic discussions, until now comparatively few papers have scrutinized the interaction of both, i.e. the role of exchange rates for wage setting in Central and Eastern Europe. According to Mundell's (1961) seminal theory of optimum currency areas, a high degree of wage flexibility is required if exchange rates are irrevocably fixed and heterogeneity within the monetary union remains high. Based on this criterion, Paas et al. (2002), Belke and Kaas (2004), Gruber (2004), Iara and Traistaru (2004) and Babestskii (2007) among others, have analyzed the degree of wage flexibility in CEE. 
Belke and Setzer (2003) and Belke et al. (2004) are considering the impact of exchange rate volatility on labor markets in CEE. They argue that exchange rate volatility vis-à-vis the euro significantly contributes to higher unemployment. Schnabl (2008) studies the effect of exchange rate volatility on economic growth in the EMU periphery. He argues that exchange rate stability provides more certainty for the wage bargaining process in small open economies and thereby leads to higher growth and wages.

We will build upon this discussion by examining which exchange rate strategy provides a more favorable framework for the wage setting process in emerging markets leading to faster wage growth in CEE. The investigation will be based on the seminal Lindbeck model of wage convergence during the economic catch-up which will be tested empirically.

\section{Theoretical Framework of Exchange Rate Regimes and Wage Determination}

The literature dealing with wage determination and exchange rates goes back to the Bretton Woods era. Friedman (1953), Meade (1951) and Mundell (1961) saw exchange rate flexibility as a substitute for wage rigidity in the face of asymmetric shocks. Given flexible exchange rates and rigid wages in small open economies (as they prevail in CEE), a negative (positive) productivity shock is offset by currency depreciation (appreciation). Monetary expansion and depreciation are seen as Keynesian tools to address deflationary shocks and sustain growth and welfare.

In contrast, in the Scandinavian model of wage adjustment (Lindbeck 1979) fixed exchange rates provide a more stable and growth enhancing framework for wage determination in small open economies during the economic catch-up process. In this dynamic extension of the BalassaSamuelson model (Balassa 1964, Samuelson 1964), fixed exchange rates lead to more certainty in the wage bargaining process as enterprises and trade unions can rely on a more stable macroeconomic environment for the wage bargaining process. The outcome is higher wages than under flexible exchange rate regimes.

In this paper we apply Lindbeck's (1979) approach to CEE. The Scandinavian model which goes back to a group of Norwegian (see Aukrust, Holte and Stoltz 1967) and Swedish 
economists (Edgren, Gösta, Faxén and Odhner 1970) and was summarized by Lindbeck (1979) ${ }^{1}$ was designed to explain the wage adjustment of the Scandinavian countries in the economic catch-up versus the US. Under the Bretton Woods System of fixed dollar parities, during the 1950s and 60s, Sweden along with Norway and Denmark were among Western Europe’s fastest growing economies. In contrast to the CEE countries today, where different exchange rate strategies coexist, all Scandinavian countries fixed their currencies to the dollar. The Scandinavian model of wage adjustment had the basic idea that nominal wage growth is driven by productivity increases and inflation. Domestic inflation was expressed in terms of world inflation and exchange rate developments.

One basic assumption of the Lindbeck model is that purchasing power parity holds: Given perfect arbitrage, domestic price inflation in the tradable good sector $\Delta p_{T}^{d}$ is assumed to be equal to inflation on world traded good markets (measured in terms of the dominant international money) labeled as $\Delta p_{T}^{W}$, plus the rate of currency appreciation/ depreciation $\Delta e$. Formally,

$$
\Delta p_{T}^{d}=\Delta p_{T}^{W}+\Delta e,
$$

While Lindbeck assumed the dollar to be the dominant international money, we assume that the euro is the dominant reference currency for CEE as most international goods and financial flows in CEE are denominated in euros (ECB 2008). The Scandinavian authors in the 1960s did not consider exchange rates to be important policy variables since the Scandinavian exchange rates were tightly fixed to the dollar and exchange rate changes were (close to) zero. They assumed that arbitrage in international traded goods markets ensured that inflation in the domestic traded goods sector converged to inflation in the dollar denominated world traded goods markets as in equation (1).

Lindbeck (1979) further assumed that the wage bargaining process was initiated in the (industrial) tradable goods sector, where labor productivity tends to grow faster than in the nontradable (service) sector. ${ }^{2}$ As workers are aware of increasing productivity, they bargain fiercely

1 For an empirical analysis of the Lindbeck model for the Scandinavian countries see Forslund et al. (2006).

2 In contrast, Goretti (2008) argues that the wage bargaining process may start in the (non-traded goods) public sector and is transmitted to the other sectors of the economy. 
for respective wage increases. Let $\Delta q_{T}^{d}$ be the productivity growth in the tradable sector, reflecting increasing stocks of human and physical capital. The trade unions in the "unsheltered" tradable sector are assumed to orient their wage bargaining on productivity gains plus eventual price increases of tradable goods world market prices $\Delta p_{T}^{d}$. Therefore, the average rate of the nominal wage increases in the tradable sector $\Delta w_{T}^{d}$ is characterized by:

$$
\Delta w_{T}^{d}=\Delta p_{T}^{d}+\Delta q_{T}^{d}
$$

According to Lindbeck in small open economies (such as in CEE) the wage bargaining process can be regarded as being constrained by fixed exchange rates. If trade unions bargain for nominal wage increases beyond equation (2), manufacturing goods become uncompetitive in world markets with a fall in employment. ${ }^{3}$ While wage increases beyond equation (2) may be possible in the short-run, in the long-run trade unions would return to equation (2) to avoid rising structural unemployment. Thus, equation (2) defines the natural (long-run) rate of nominal wage increases in a small open economy. As long as inflation in world prices $p_{T}^{W}$ remains low and fairly predictable, workers are content to bargain for the concurrent trends in domestic productivity growth and world inflation.

As in the Balassa-Samuelson framework, Lindbeck (1979) assumed that labor "solidarity" and labor mobility between the manufacturing sector and the non-tradable sectors transmit the manufacturing wage increases to wage increases in the service sector $w_{N T}^{d}$ :

$$
\Delta w_{T}^{d}=\Delta w_{N T}^{d}=\Delta w^{d}
$$

where $\Delta w^{d}$ denotes the wage growth in the whole economy. As the non-tradable sectors were widely shielded from world markets, prices in these sectors were assumed not to be driven by international competition but would be based on domestic labor costs. Thus, the price increases in

3 It is argued for instance, that recently the real wage increases in the Baltics and Hungary have gone beyond productivity increases. 
the non-tradable sector $\Delta p_{N T}^{d}$ are a function of wage increases $\Delta w_{N T}^{d}$ subtracting the productivity gains in the non-traded goods sector $\Delta q_{N T}^{d}$, where productivity increases in the non-tradable (service) sector were assumed to be smaller than in the traded goods sector:

$$
\Delta p_{N T}^{d}=\Delta w_{N T}^{d}-\Delta q_{N T}^{d} \text {, with } \Delta q_{N T}^{d}<\Delta q_{T}^{d}
$$

The equations (1), (2), (3) and (4) yield equation (5) which shows the impact of world market prices, exchange rate changes and relative sectoral productivity gains on prices of non-traded goods:

$$
\Delta p_{N T}^{d}=\Delta p_{T}^{W}+\Delta e+\Delta q_{T}^{d}-\Delta q_{N T}^{d} .
$$

In the Scandinavian model, the wage bargaining and price adjustment processes in the traded and non-traded goods sectors affect general inflation $\Delta p^{d}$, which is defined as a composite of traded goods inflation and non-traded goods inflation given the respective weights $\alpha$ and $(1-\alpha)$ in the consumer basket:

$$
\Delta p^{d}=\alpha \Delta p_{T}^{d}+(1-\alpha) \Delta p_{N T}^{d}
$$

Inserting equations (1), (5) and (6) yield equation (7) which can be interpreted as an overall measure for supply-driven inflation in a small open economy in the economic catch-up process:

$$
\Delta p^{d}=\left(\Delta p_{T}^{W}+\Delta e\right)+(1-\alpha)\left(\Delta q_{T}^{d}-\Delta q_{N T}^{d}\right)
$$

In equation (7) the term $\left(\Delta p_{T}^{W}+\Delta e\right)$ is equivalent to imported inflation. If world market prices in the traded goods sector rise (fall) and/or if the exchange rate depreciates (appreciates), this would fuel domestic inflation (deflation). The term $(1-\alpha)\left(\Delta q_{T}^{d}-\Delta q_{N T}^{d}\right)$ captures the structural component of inflation, which is in line with the Balassa-Samuelson effect of supply driven 
inflation (Balassa 1964 and Samuelson 1964). ${ }^{4}$ Relative productivity gains in the tradable goods sector $\left(\Delta q_{T}^{d}-\Delta q_{N T}^{d}>0\right)$ are translated via the wage bargaining process into higher inflation. The greater the weight of the non-tradable goods sector in the economy $(1-\alpha)$, or the larger the difference between productivity growth of the tradable and the non-tradable goods sector, the larger the impact on domestic inflation.

\section{Wage Adjustment in Labor Markets under Alternative Exchange Rate Regimes}

Whereas the Lindbeck model was originally constructed for the Scandinavian countries which pegged their currencies to the dollar, today the CEE countries can choose their exchange rate strategies (see Table 1): The Baltics have chosen a hard peg to the euro within the Exchange Rate Mechanism 2 and aim to adopt the euro as a legal tender as soon as possible. In contrast, the monetary authorities of Czech Republic, Hungary and Poland have implemented an inflation targeting frameworks and let their exchange rates float (more or less) freely. They have continued to postpone the euro adoption targets.

Figure 1 shows the de facto quarterly exchange rate changes of the CEE countries currencies against the euro (before 1999 the DM). There are two clusters. The first group of countries, namely Czech Republic, Slovak Republic, Hungary and Poland allowed their exchange rate to float to a high degree, while the second group, the Baltic countries and Slovenia, exhibit low exchange rate volatility against the euro. The Estonian currency board is pegging the kroon tightly to the euro (or DM) in the whole observation period. Lithuania and Latvia pegged their currencies to the dollar and a currency basket before pegging them to the euro. With the introduction of the euro in January 2009, Slovakia will shift from widely flexibly to a "tightly fixed” exchange rate. Choosing alternative exchange rate strategies will have different implications for the wage setting process in the economic catch-up. Following De Grauwe and Schnabl (2005), we show that the industrial catch-up of emerging markets under alternative exchange rate strategies leads to two alternative outcomes depending on the monetary framework: First, if exchange rates are pegged, the relative productivity gains drive up prices as in the seminal Balassa-Samuelson model.

4 Schnabl (2008) discusses the possible shortcomings of the Balassa-Samuelson approach. 
Table 1: Exchange rate strategies in CEE in 2008

\begin{tabular}{|c|c|c|}
\hline Country & Current exchange rate system & Euro adoption \\
\hline $\mathrm{CZ}$ & $\begin{array}{l}\text { Free floating with inflation target since } \\
\text { 1997, from } 1995 \text { till } 1997 \text { managed } \\
\text { float }\end{array}$ & $\begin{array}{l}\text { The preliminary target date (1 January 2010) } \\
\text { was withdrawn by the government on } 25 \\
\text { October } 2006 \text {. No new date has been officially } \\
\text { set for the time being. }\end{array}$ \\
\hline $\mathrm{EE}$ & $\begin{array}{l}\text { Currency board with a hard peg to the } \\
\text { euro within the ERM II (since June } \\
\text { 2004) }\end{array}$ & $\begin{array}{l}\text { EE targets euro area membership as soon as } \\
\text { possible ( } 2011 \text { being the earliest possible } \\
\text { envisaged date according to current inflation } \\
\text { forecasts). }\end{array}$ \\
\hline $\mathrm{HU}$ & $\begin{array}{l}\text { Free floating since March 2008, before } \\
\text { managed floats, with inflation target } \\
\text { since } 2002\end{array}$ & $\begin{array}{l}\text { The Convergence Programme of } 1 \text { December } \\
2006 \text { aims at meeting the Maastricht criteria in } \\
\text { 2009. A new target date for the adoption of the } \\
\text { euro has not been specified. }\end{array}$ \\
\hline $\mathrm{LT}$ & $\begin{array}{l}\text { Currency board with a hard peg to the } \\
\text { euro within the ERM II (since June } \\
\text { 2004), before hard dollar peg }\end{array}$ & $\begin{array}{l}\text { The specific target date has not been set. } \\
\text { According to the government, LT will aim to } \\
\text { join the euro area as soon as possible and the } \\
\text { more favourable period to join starts from } 2010 \text {. }\end{array}$ \\
\hline LV & $\begin{array}{l}\text { Currency board with a hard peg to the } \\
\text { euro within the ERM II (since May } \\
\text { 2005), before currency basket }\end{array}$ & The specific target date has not been set. \\
\hline $\mathrm{PL}$ & $\begin{array}{l}\text { Free floating with inflation target since } \\
\text { 2000, from } 1995 \text { till } 2000 \text { managed } \\
\text { float }\end{array}$ & The specific target date has not been set. \\
\hline SK & $\begin{array}{l}\text { ERM II membership (exchange rate } \\
\text { with } 15 \text { percent fluctuation band) since } \\
\text { November 2005, before managed floats }\end{array}$ & January 2009 \\
\hline SI & $\begin{array}{l}\text { EMU membership since January 2007, } \\
\text { before ERM II membership (exchange } \\
\text { rate with } 15 \text { percent } \\
\text { fluctuation band) since June } 2004\end{array}$ & January 2007 \\
\hline
\end{tabular}

Source: ECB (2008) and European Commission (2007). 
Figure 1: Exchange rate changes, quarter-over-quarter
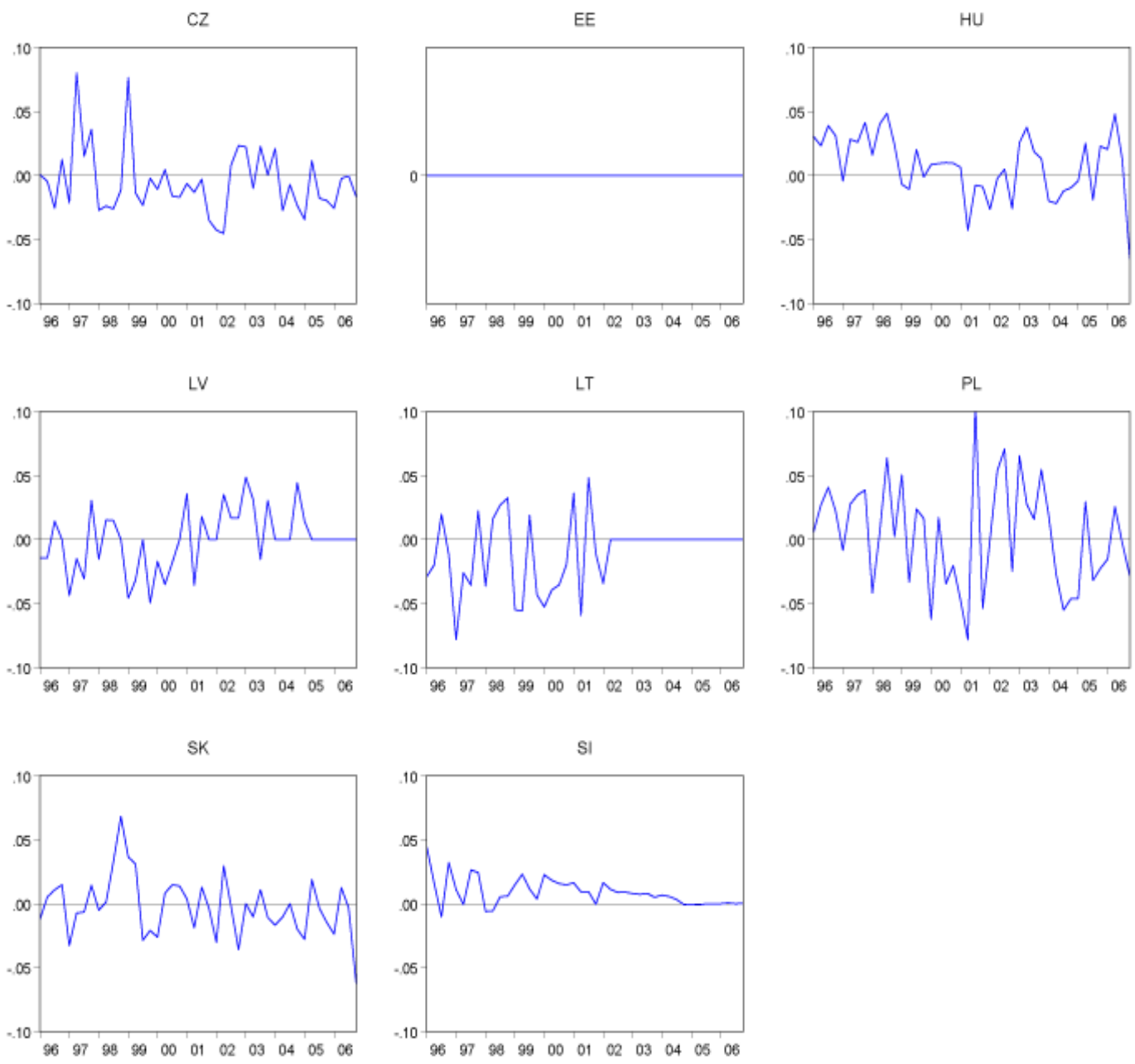

Source: IMF, 2008.

Second, if exchange rates are freely floating and the central banks follow an inflation target, relative productivity gains are accompanied by nominal appreciation. Even if both monetary frameworks can be seen as equal policy choices to engineer the real appreciation which is the natural outcome of industrial catch-up, exchange rate volatility and sustained nominal appreciation may increase uncertainty in labor markets. 
Based on the Scandinavian model we derive the implication for the wage determination process in emerging markets under alternative exchange rate regimes. From equation (2), (3) and (4) we define the overall wage growth as the sum of overall productivity growth and inflation:

$$
\Delta w^{d}=\Delta p^{d}+\Delta q^{d}
$$

where $\Delta q^{d}$ denotes the overall general domestic productivity growth, which is a composite of traded goods and non-traded goods productivity growth given the respective weights $\rho$ and $(1-\rho):$

$$
\Delta q^{d}=\rho \Delta q_{T}^{d}+(1-\rho) \Delta q_{N T}^{d}
$$

Inserting equations (7) and (9) in (8) yields equation (10), which can be interpreted as a measure for the overall long-run supply driven nominal wage growth in CEE:

$$
\Delta w^{d}=\tau\left(\Delta q_{T}^{d}-\Delta q_{N T}^{d}\right)+\left(\Delta p_{T}^{W}+\Delta e\right)
$$

where $\tau=(\rho-\alpha+1)$ is a positive constant term. According to equation (10) nominal wage growth is driven by productivity gains of the tradable goods sector relative to the non-tradable goods sector as well as by imported inflation in the traded goods sector and exchange rate changes $\Delta p_{T}^{W}+\Delta e$.

The wage setting process can occur within two institutional environments. In countries pegging their exchange rates tightly to the euro, for instance Lithuania, Latvia or Estonia, the term $\Delta e$ is equal (or close) to zero. This reduces the uncertainty for the wage bargaining process, because trade unions and enterprises have solely to predict future productivity gains and traded goods inflation. In addition, in the Lindbeck model it is assumed that the biddings of trade unions for higher wages are constrained by the fixed exchange rate. Trade unions reap the full benefits of productivity gains and equilibrate the international competitiveness between CEE and the euro area. But, trade unions would not want to ask for wage increases above domestic productivity 
gains as this would erode the enterprises' international competitiveness. If they would bid for wage increases above this level, profits of enterprises would shrink and entrepreneurs would be less willing to increase wages in the next bargaining period.

In countries with freely floating exchange rates such as Poland or the Czech Republic an additional factor of uncertainty is introduced into the wage bargaining process as exchange rate volatility is high. To project future profits the enterprises in CEE have to know how the future exchange rate will be. If the exchange rate is regarded as an asset price which follows a random walk, there is uncertainty because the exchange rate may appreciate or depreciate. If - due to the Balassa-Samuelson effect - firms expect an appreciation of the domestic currency, they are reluctant to commit to wage increases as export revenues may decline. Therefore, we follow McKinnon and Schnabl (2006) and include a risk premium $\psi$ in equation (10), which captures discounts on wages originating in uncertainty arising from exchange rate fluctuations. The risk premium is assumed to be negative as (parts of) the costs of this uncertainty are passed through to workers. This implies:

$$
\Delta w^{d}=\tau\left(\Delta q_{T}^{d}-\Delta q_{N T}^{d}\right)+\left(\Delta p_{T}^{W}+\Delta e\right)+\psi
$$

While in countries with an exchange rate peg $\psi$ and $\Delta e$ are assumed to be (close to) zero, the exchange rate uncertainty in countries with flexible exchange rate regimes implies a negative risk premium on wages $(\psi<0)$.

\section{Estimation Framework}

We investigate whether equation (11) holds for the CEE countries from an inter-temporal and cross-section perspective. We include eight CEE countries in our panel, which entered the European Union in May 2004, namely Czech Republic (CZ), Estonia (EE), Hungary (HU), Lithuania (LT), Latvia (LV), Poland (PL), Slovak Republic (SK), and Slovenia (SI). Bulgaria and Romania, which joined the European Union in January 2007, are omitted due to missing (wage) data. 


\subsection{Data}

Our sample starts in the first quarter of 1996 and ends with the second quarter of 2007. Before 1996 data on the former transition economies is very fragmented. We use quarterly data, which is the smallest available frequency for all considered time series. ${ }^{5}$ Nominal gross wages are from national statistics. Exchange rates (quarterly averages), inflation and productivity are drawn from Eurostat and IMF International Financial Statistics. Euro area tradable goods prices $p_{T}^{W}$ are proxied by German export prices as export prices for the euro area are not available, and Germany is the largest country in the euro area. ${ }^{6}$ As a proxy for productivity we use nominal GDP per capita, because industrial and service sector production per employee are not available for the whole time period for every country at quarterly frequencies. As alternative productivity measure we use the ratio of consumer (CPI) to producer prices (PPI) analogous to De Grauwe and Schnabl (2005). Following Balassa (1964) and Samuelson (1964), this measure regards relative price increases of non-traded goods versus traded goods as a proxy for relative productivity gains.

The quarterly averages of exchange rates are in price notation, which implies that a negative exchange rate change indicates an appreciation of the national currency against the euro. As proxies for the risk premium arising from exchange rate volatility we use the absolute and squared values of exchange rate returns. In addition, we consider intra-quarter realized volatilities, standard deviations of daily exchange rate changes and the z-score as proposed by Ghosh, Gulde and Wolf (2003). With the exception of the volatility measures all time series are year-over-year quarterly growth rates.

\subsection{Descriptive Statistics}

Equation (11) implies that controlling for exchange rate changes, world traded goods inflation and relative productivity changes, countries with fixed exchange rates have a higher real wage

5 To adjust data seasonally, we calculate year-over-year growth rates instead of quarter-over-quarter growth rates.

6 As alternative inflation measures, the harmonized consumer price index as well as the producer price index of the euro area (EU-12) have been used. Both proxies lead to similar results which are available upon request. 
growth. Note that domestic traded goods inflation has been substituted by euro area traded goods inflation and exchange rate changes. Therefore, the descriptive statistics focus on real wage growth. In contrast to the regressions in section 4.3., the descriptive statistics do not control for other determinants of real wages as in our Balassa-Samuelson specification. Given this caveat countries with hard pegs (to the euro) (i.e. LT, LV, EE) are expected in line with the BalassaSamuelson model to exhibit higher inflation than countries with flexible exchange rates (PL, CZ, HU, SK), and higher real wages.

Figure 2 displays the real wage growth of the CEE countries since 1996. We observe that real wage growth tends to be higher in the Baltics than in countries with flexible exchange rates. Comparing the two corner solutions, Poland (free float) and Estonia (hard peg), real wage growth in Estonia has been significantly higher than in Poland.

Table 2 displays the descriptive statistics of real wage growth in the individual countries. In general, they support the conclusions drawn from the Lindbeck model. The mean and median of real wage growth in countries with fixed exchange rates are higher than wage growth in countries with free floats; e.g. Latvia has a real wage growth of 4.4 percent per year on average, while the real wage growth of Poland is on average 2.3 percent. Estonia has with an average real wage growth of 6.3 percent the greatest wage growth, while the Slovak Republic with a real wage growth of 2.1 percent has the smallest.

A t-test $\left(\mathrm{t}_{1}\right)$ which analyzes whether the individual means differ from the group mean, indicates that all means are different from the pooled mean. The average real wage growth of countries with a fixed exchange rate peg is significantly higher wage growth than the group mean, while in countries with flexible exchange rates - with the exception of Czech Republic - the average wage growth is below the pooled wage growth of 3.8 percent. $^{7}$ The F-test provides information with respect to equality of all means. The null hypothesis of equal means is rejected for all countries which implies that the average real wage growth differs between all new member states.

7 An alternative t-test $\left(\mathrm{t}_{2}\right)$ shows that the individual means are significantly different from zero. 
Figure 2: Real wage growth, year-over-year
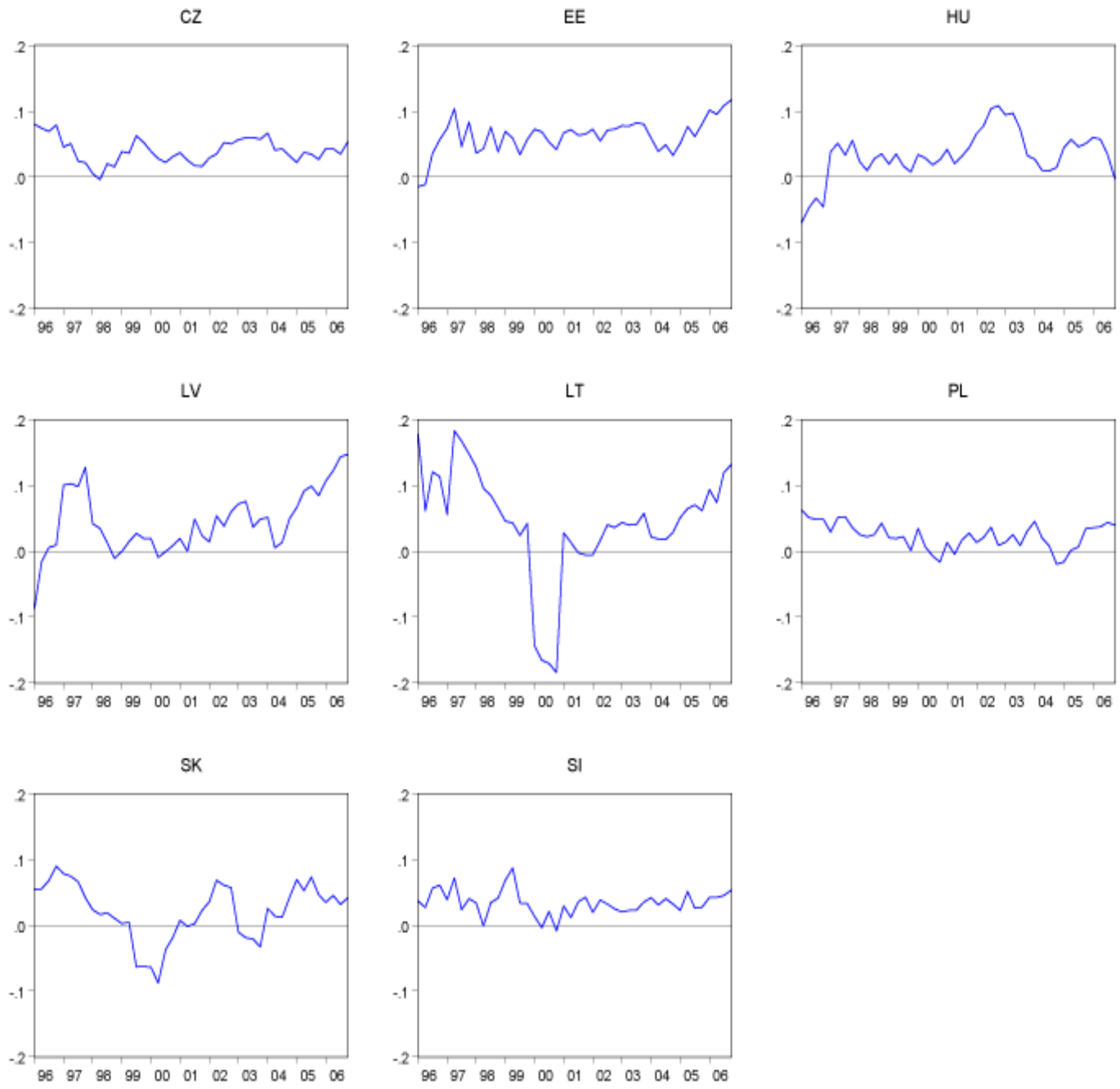

Source: National statistics, 2008 (drawn from Reuters Econwin).

The Fisher-ADF panel unit root test (Choi 2001, Madalla and Wu (1999)) is based on individual p-values for the unit root hypothesis which are combined in a second step to obtain an overall pvalue. It does not find evidence for unit roots in the investigated panel. Henceforth, neither panel cointegration nor spurious regressions are a matter of concern. Motivated by these findings, we examine if there is a positive systematic relationship between exchange rate stability and wage growth in CEE. 
Table 2: Descriptive statistics, real wage growth (y-o-y, quarterly data)

\begin{tabular}{|c|c|c|c|c|c|c|c|c|}
\hline Country & Mean & Median & Max. & Min. & Std. dev. & Obs. & $\mathrm{t}_{1}$ & $\mathrm{t}_{2}$ \\
\hline $\mathrm{CZ}$ & 0.040 & 0.038 & 0.080 & -0.004 & 0.019 & 44 & $\begin{array}{l}12.243 \\
(0.000)\end{array}$ & $\begin{array}{c}5.430 \\
(0.000)\end{array}$ \\
\hline $\mathrm{EE}$ & 0.063 & 0.066 & 0.118 & -0.015 & 0.026 & 44 & $\begin{array}{l}15.317 \\
(0.000)\end{array}$ & $\begin{array}{l}10.203 \\
(0.000)\end{array}$ \\
\hline HU & 0.033 & 0.034 & 0.109 & -0.070 & 0.037 & 44 & $\begin{array}{r}-11.247 \\
(0.000)\end{array}$ & $\begin{array}{r}-13.788 \\
(0.000)\end{array}$ \\
\hline LV & 0.045 & 0.037 & 0.147 & -0.087 & 0.048 & 44 & $\begin{array}{c}6.678 \\
(0.000)\end{array}$ & $\begin{array}{c}4.097 \\
(0.000)\end{array}$ \\
\hline $\mathrm{LT}$ & 0.044 & 0.045 & 0.184 & -0.185 & 0.083 & 44 & $\begin{array}{c}6.518 \\
(0.000)\end{array}$ & $\begin{array}{c}4.185 \\
(0.000)\end{array}$ \\
\hline PL & 0.023 & 0.024 & 0.063 & -0.019 & 0.020 & 44 & $\begin{array}{c}5.217 \\
(0.000)\end{array}$ & $\begin{array}{c}2.739 \\
(0.000)\end{array}$ \\
\hline SK & 0.021 & 0.034 & 0.091 & -0.088 & 0.042 & 44 & $\begin{array}{c}3.885 \\
(0.000)\end{array}$ & $\begin{array}{c}3.122 \\
(0.000)\end{array}$ \\
\hline SI & 0.034 & 0.037 & 0.087 & -0.0085 & 0.018 & 44 & $\begin{array}{l}-3.548 \\
(0.001)\end{array}$ & $\begin{array}{l}-9.343 \\
(0.000)\end{array}$ \\
\hline All & 0.038 & 0.031 & 0.184 & -0.185 & 0.043 & 352 & & \\
\hline$F$ & 63.971 & $(0.000)$ & & & & & & \\
\hline
\end{tabular}

Notes: $t_{2}$ is the t-statistic for the hypothesis that the mean is zero. $t_{1}$ is the t-statistic for the null hypothesis that the individual mean does not significantly differ from the overall group mean. $F$ is an F-statistic for the hypothesis that all means are equal. P-values are reported in parentheses.

\subsection{Estimation framework}

We estimate the Lindbeck model as in equation (11) for a CEE cross-country panel to identify the impact of exchange rate volatility on nominal wage growth. To specify the model properties we test for random effects against fixed effects.

The Hausman-test gives a chi-squared distributed statistic of 2.184, and a p-value of 0.702 in favor of a random effects specification. 
Based on equation (11) we estimate the following model:

$\Delta w_{i t}=\bar{\mu}+\beta \Delta q_{i t}^{\text {diff }}+\lambda \Delta p_{t}^{W}+\gamma \Delta e_{i t}+\phi \psi_{i t}+u_{i t} \quad$ with $u_{i t}=\mu_{i}+v_{i t}$,

where $\Delta q_{i t}^{\text {diff }}$ is the productivity differential, $i=1, . ., 8$ denotes the cross-section and $t=1996 Q 1, \ldots, 2007 Q 2$ the time dimension. The term $\bar{\mu}$ denotes the overall constant, while $\mu_{i}$ denotes the country-specific deviations from $\bar{\mu}$. The random effects specification assumes that the country-specific effects are realizations of independent random variables with mean zero and finite variance. Most importantly, the random effect specification assumes that the individual country specific effect is uncorrelated with the idiosyncratic residual $v_{i t}$. The estimation of the covariance matrix for the composite error uses the quadratic unbiased estimators from SwamyArora. The parameters are estimated with generalized panel least squares and we use White period standard errors (White 1980, Arellano 1987) to cope with possible cross-sectional heteroscedasticity and serial correlation.

\subsection{Results}

The estimation results are reported in Table 3 for the baseline regressions, where equation (12) is estimated with GDP per capita growth as productivity measure, German export price inflation as proxy for international traded goods prices, exchange rate changes in price notation and the different volatility measures described in the data section.

In the baseline regression (Table 3, column 1) with squared exchange rate changes as volatility measure all estimated parameters have the expected sign. The productivity measure and the exchange rate term are significant at the common levels. In the lower part of the table the individual country effects $\mu_{i}$ are displayed. To derive individual constant terms the countryspecific terms have to be added to the overall constant term. The country specific constant terms are in comparison to a fixed effect model not deterministic, but random. This allows capturing country-specific effects in our heterogeneous panel. However, due to its random character, the different random effects can not be compared with each other. 
All signs of the estimates are congruent with the Lindbeck model. Increasing productivity (positive $\beta$ term) is linked to increasing wages at the common significance levels. Changes in German export prices (as proxy for euro area traded goods inflation) ( $\lambda$ term) have no significant impact on nominal wage growth. ${ }^{8}$ The $\gamma$ coefficient, which captures the impact of exchange rate changes on wages, has the expected positive sign at the $1 \%$ significance level.

If home currency is appreciating (depreciating) against the euro $(e<0(e>0))$ nominal wages decline (increase). This implies that the exchange rate regime has a significant impact on wage determination in the eight analyzed CEE countries.

Among productivity growth, euro area tradable goods inflation and exchange rate changes, exchange rate changes have the highest impact on nominal wage growth as indicated by the largest coefficient. A ten percent exchange rate appreciation (depreciation) is linked to roughly five percentage points lower (higher) wage growth.

Table 3 reports our baseline regression with different volatility measures to check the sensitivity of our results. Alternatively to squared returns, we consider absolute exchange rate changes (modulus) as well as a realized volatility measure that is based on daily intra-quarter information (for the compilation see Andersen et al. 2003). Realized volatility aggregates information from higher frequencies to obtain more accurate estimates of unobserved intra-period volatility. Another volatility measure is the standard deviation of daily exchange rate changes. The z-score (the root of the squared mean of exchange rate changes and its variances) as proposed by Ghosh, Gulde and Wolf (2003), links exchange rate changes and its standard deviation.

Estimating equation (13) with different volatility measures does not change our main conclusion. All parameters originating in the Lindbeck model remain widely unchanged. Productivity growth increases nominal wage growth, while tradable goods inflation in the euro area has no significant impact on wages. Currency appreciation (depreciation) against the euro lowers (increases) nominal wage growth. The size of the coefficients $\beta, \lambda$ and $\gamma$ remains widely the same.

8 In a shorter sample which starts in 1999 the $\lambda$-terms turns positive and significant. 
Table 3: Panel estimation results, baseline regressions

\begin{tabular}{|c|c|c|c|c|c|}
\hline & Squared returns & Absolute returns & Realized volatility & Std. dev. & Z-score \\
\hline \multirow{2}{*}{$\bar{\mu}$} & $0.057 * * *$ & $0.057 * * *$ & $0.056 * * *$ & $0.052 * * *$ & $0.053^{* * *}$ \\
\hline & $(0.017)$ & $(0.018)$ & $(0.018)$ & $(0.018)$ & $(0.017)$ \\
\hline \multirow{2}{*}{$\Delta q_{i t}^{\text {diff }}$} & $0.429 * *$ & $0.433 * *$ & $0.433 * *$ & $0.441^{* *}$ & $0.446^{* *}$ \\
\hline & $(0.176)$ & $(0.177)$ & $(0.172)$ & $(0.177)$ & $(0.189)$ \\
\hline \multirow{2}{*}{$\Delta p_{t}^{W}$} & 0.005 & -0.004 & -0.018 & -0.021 & -0.049 \\
\hline & $(0.358)$ & $(0.363)$ & $(0.357)$ & $(0.366)$ & (0.379) \\
\hline \multirow{2}{*}{$\Delta e_{i t}$} & $0.539 * * *$ & $0.535 * * *$ & $0.535 * * *$ & $0.522 * * *$ & $0.509 * * *$ \\
\hline & $(0.165)$ & $(0.165)$ & $(0.166)$ & $(0.167)$ & $(0.172)$ \\
\hline \multirow{2}{*}{$\psi_{i t}$} & -0.008 & $-0.088^{*}$ & -0.002 & 0.002 & -0.001 \\
\hline & $(0.006)$ & $(0.049)$ & $(0.002)$ & $(0.001)$ & $(0.002)$ \\
\hline$\mu_{C Z}$ & -0.002 & -0.002 & -0.001 & -0.002 & -0.004 \\
\hline$\mu_{E E}$ & 0.000 & 0.000 & 0.000 & 0.002 & 0.003 \\
\hline$\mu_{H U}$ & 0.006 & 0.005 & 0.002 & 0.003 & 0.014 \\
\hline$\mu_{L V}$ & 0.006 & 0.006 & 0.003 & 0.008 & 0.014 \\
\hline$\mu_{L T}$ & -0.004 & -0.005 & -0.002 & -0.005 & -0.013 \\
\hline$\mu_{P L}$ & -0.004 & -0.003 & -0.002 & -0.005 & -0.011 \\
\hline$\mu_{S K}$ & -0.004 & -0.004 & -0.002 & -0.004 & -0.009 \\
\hline$\mu_{S I}$ & 0.001 & 0.002 & 0.001 & 0.002 & 0.006 \\
\hline$\overline{\bar{R}^{2}}$ & 0.319 & 0.316 & 0.321 & 0.312 & 0.332 \\
\hline obs & 352 & 352 & 352 & 352 & 352 \\
\hline
\end{tabular}

Notes: White period standard errors. Standard deviations are reported in parentheses below estimates. ***/**/* indicates that values are significantly different from 1 at the $1 / 5 / 10$ percent level. $\bar{R}^{2}$ denotes the adjusted coefficient of determination. obs shows the total number of observations.

The results for different measures of exchange rate volatility differ within the regressions. Absolute returns, realized volatility, and the z-score proxies for uncertainty have the expected negative sign but only the absolute returns are statistically significant at the common levels. In contrast, the $\phi$ coefficient is positive for the standard deviation but remains insignificant. 
The estimated country-specific $\mu_{i}$ coefficients show (for all regressions) that with the exception of Hungary and Lithuania, countries pegging their exchange rate to the euro have a higher country-specific constant term. All in all, the evidence for a significant effect of the exchange rate regime on wages is strong as all exchange rate terms and four out of five of the risk premiumterms have the expected sign mostly at significant levels.

\subsection{Robustness Checks}

We have performed a set of robustness checks. First, we estimated our baseline regressions with an alternative productivity measure. Relative changes of consumer versus producer prices were used as a proxy for relative productivity changes. The estimated results are reported in Table 4.

As in the baseline regression from the previous section, higher productivity growth is linked to higher wage growth. Euro area tradable goods inflation has, in contrast to the previous estimation, a positive and significant influence on wage growth. A currency appreciation lowers wage growth (positive $\gamma$ coefficient). The impact of exchange rate changes on wages is however smaller than in the baseline regressions. A currency appreciation (depreciation) of around ten percent is transmitted via the wage bargaining process into three percent lower (higher) wages. The results are very robust throughout the set of different volatility measures. Euro area tradable goods inflation has the highest impact on nominal wages followed by productivity growth and exchange rate changes.

The $\phi$-coefficient isolates the discount on wages due to uncertainty originating in exchange rate volatility. Exchange rate volatility has a significant negative impact on nominal wages when using the squared and absolute exchange rate returns as proxies for exchange rate volatility. Realized volatility, standard deviations as well as the z-score enter the equation insignificantly. To this end, the evidence for lower wages due to exchange rate volatility is mixed. For all regressions country-specific effects are similar to those in the baseline regression. But for Slovenia the country-specific effect turns negative, indicating a smaller constant term than average. 
Table 4: Panel estimation results, alternative productivity measure

\begin{tabular}{|c|c|c|c|c|c|}
\hline & Squared returns & Absolute returns & Realized volatility & Std. dev. & Z-score \\
\hline \multirow{2}{*}{$\bar{\mu}$} & $0.081^{* * *}$ & $0.083 * * *$ & $0.078 * * *$ & $0.075 * * *$ & $0.075 * * *$ \\
\hline & $(0.005)$ & $(0.007)$ & $(0.006)$ & $(0.007)$ & $(0.007)$ \\
\hline \multirow{2}{*}{$\Delta q_{i t}^{\text {diff }}$} & & & & $0.466^{* * *}$ & $0.466 * * *$ \\
\hline & $(0.085)$ & $(0.070)$ & (0.099) & $(0.101)$ & $(0.101)$ \\
\hline \multirow{2}{*}{$\Delta p_{t}^{W}$} & $0.954 * * *$ & $0.975 * * *$ & $0.096 * * *$ & $0.968 * * *$ & $0.968 * * *$ \\
\hline & $(0.364)$ & $(0.217)$ & $(0.036)$ & $(0.362)$ & $(0.363)$ \\
\hline \multirow{2}{*}{$\Delta e_{i t}$} & $0.268 * * *$ & $0.271 * * *$ & $0.271^{* * *}$ & $0.268 * * *$ & $0.269 * * *$ \\
\hline & $(0.053)$ & $(0.048)$ & $(0.059)$ & $(0.064)$ & $(0.064)$ \\
\hline \multirow{2}{*}{$\psi_{i t}$} & $-0.015 * *$ & $-0.168 * *$ & -0.002 & 0.001 & 0.000 \\
\hline & $(0.006)$ & $(0.071)$ & $(0.002)$ & $(0.002)$ & $(0.001)$ \\
\hline$\mu_{C Z}$ & -0.010 & -0.009 & -0.009 & -0.010 & -0.010 \\
\hline$\mu_{E E}$ & 0.013 & 0.011 & 0.014 & 0.017 & 0.017 \\
\hline$\mu_{H U}$ & 0.019 & 0.018 & 0.017 & 0.016 & 0.017 \\
\hline$\mu_{L V}$ & 0.005 & 0.005 & 0.004 & 0.005 & 0.005 \\
\hline$\mu_{L T}$ & -0.005 & -0.006 & -0.006 & -0.006 & -0.006 \\
\hline$\mu_{P L}$ & -0.008 & -0.008 & -0.009 & -0.012 & -0.012 \\
\hline$\mu_{S K}$ & -0.006 & -0.005 & -0.005 & -0.005 & -0.005 \\
\hline$\mu_{S I}$ & -0.008 & -0.007 & -0.006 & -0.005 & -0.005 \\
\hline $\bar{R}^{2}$ & 0.188 & 0.181 & 0.172 & 0.166 & 0.166 \\
\hline obs & 320 & 320 & 320 & 320 & 320 \\
\hline
\end{tabular}

Notes: White period standard errors. Standard deviations are reported in parentheses below estimates. ***/**/* indicates that values are significantly different from 1 at the 1/5/10 percent level. $\bar{R}^{2}$ denotes the adjusted coefficient of determination. obs shows the total number of observations.

The estimates can be subject to endogeneity bias, in particular with respect to the productivity measures. Higher productivity may drive up wages, but higher wages could also influence productivity. To address this possible endogeneity bias, we implement an instrumental variable estimator (IV). We use a two-stage least squares estimator with White period standard errors 
(White 1980). Up to four lags of the endogenous variable as well as of the exogenous variables are used as instruments. The results are shown in Table 5.

The Lindbeck model is widely confirmed for CEE countries and the evidence for a negative impact of exchange rate uncertainty on wage growth is strong. Productivity growth increases wage growth (for the specifications with realized volatility, standard deviation and z-score at highly significant levels). Euro area tradable goods inflation has no significant influence on wages. Exchange rate changes contribute to lower wage growth in times of appreciation. A ten percent appreciation (depreciation) is associated with about five percent lower (higher) wages. Exchange rate volatility has a clearly negative impact on wages for most proxies ( $\phi$-term). When using squared returns, absolute exchange rate returns or the z-score as proxies the coefficients are negative and highly significant. Otherwise the impact is insignificant. As in the previous regressions, the country specific constant terms remain stable.

All in all we can summarize that there is a high and significant negative relationship between exchange rates and nominal wage growth. The wage bargaining process seems to be strongly influenced under flexible exchange rates. Trade unions and enterprises are forced to predict exchange rate changes next to productivity growth which inputs further uncertainty in the wage determination process. This may result in bargaining for smaller wage increases due to possible losses in competitiveness. The impact of exchange rate volatility on wage growth remains mixed.

In some specifications exchange rate uncertainty is linked with decreasing wages, but in some specifications this effect turns out to be insignificant. Nonetheless, based on the Lindbeck framework our results provide us evidence that the exchange rate regime significantly influences the wage determination process in CEE.

\section{Implications for the Wage and Exchange Rate Policies}

We analyzed the role of the exchange rate on the wage determination process in CEE. Up to now exchange rate strategies differ across CEE, and there is a controversial discussion about the appropriate exchange rate system during the run-up to the EMU. 
Table 5: Panel estimation results, IV estimation

\begin{tabular}{|c|c|c|c|c|c|}
\hline & Squared returns & Absolute returns & Realized volatility & Std. dev. & Z-score \\
\hline \multirow{2}{*}{$\bar{\mu}$} & & $0.073 * * *$ & $0.053^{* *}$ & $0.039 * *$ & $0.043^{* *}$ \\
\hline & $(0.017)$ & $(0.013)$ & $(0.021)$ & $(0.020)$ & $(0.020)$ \\
\hline \multirow{2}{*}{$\Delta q_{i t}^{\text {diff }}$} & 0.245 & 0.221 & $0.398 * *$ & $0.401 * *$ & $0.566 * * *$ \\
\hline & $(0.184)$ & $(0.163)$ & $(0.197)$ & $(0.192)$ & $(0.195)$ \\
\hline \multirow{2}{*}{$\Delta p_{t}^{W}$} & 0.061 & 0.014 & -0.148 & -0.005 & -0.206 \\
\hline & $(0.408)$ & $(0.409)$ & $(0.329)$ & $(0.368)$ & $(0.886)$ \\
\hline \multirow{2}{*}{$\Delta e_{i t}$} & $0.466^{* * *}$ & $0.406^{* * *}$ & $0.491^{* *}$ & $0.490 * *$ & $0.579 * * *$ \\
\hline & $(0.151)$ & $(0.130)$ & $(0.198)$ & $(0.202)$ & $(0.180)$ \\
\hline \multirow{2}{*}{$\psi_{i t}$} & $-0.036 * * *$ & $-0.037 * * *$ & -0.006 & 0.008 & $-0.007 * *$ \\
\hline & $(0.012)$ & $(0.013)$ & $(0.006)$ & $(0.007)$ & $(0.003)$ \\
\hline$\mu_{C Z}$ & -0.002 & -0.004 & -0.000 & 0.000 & -0.000 \\
\hline$\mu_{E E}$ & 0.004 & 0.006 & 0.003 & 0.013 & -0.006 \\
\hline$\mu_{H U}$ & 0.017 & 0.025 & 0.016 & -0.001 & 0.030 \\
\hline$\mu_{L V}$ & 0.004 & 0.006 & 0.002 & 0.008 & 0.012 \\
\hline$\mu_{L T}$ & -0.022 & -0.030 & -0.024 & -0.022 & -0.036 \\
\hline$\mu_{P L}$ & 0.001 & 0.001 & -0.000 & -0.007 & -0.009 \\
\hline$\mu_{S K}$ & -0.002 & -0.003 & -0.004 & -0.001 & -0.006 \\
\hline$\mu_{S I}$ & -0.000 & -0.000 & 0.006 & 0.010 & 0.015 \\
\hline$\overline{\overline{R^{2}}}$ & 0.249 & 0.379 & 0.150 & 0.152 & 0.203 \\
\hline obs & 288 & 288 & 288 & 288 & 325 \\
\hline
\end{tabular}

Notes: White period standard errors. Standard deviations are reported in parentheses below estimates. ***/**/* indicates that values are significantly different from 1 at the 1/5/10 percent level. $\bar{R}^{2}$ denotes the adjusted coefficient of determination. obs shows the total number of observations.

The objectives of full employment, fair working conditions, productivity, employment and cohesion are at the centre of EU economic policy. In this context wage policy in CEE is an important issue for European economic policy making due to an increasing degree of labor market integration in the enlarged European Union. 
We derived from the Scandinavian model of wage determination that in emerging markets such as in CEE, trade unions could reap a higher benefit in the form of higher nominal and real wage growth in countries with a fixed exchange rate than in countries with flexible exchange rates. Therefore, it is claimed that fixed exchange rates provide a more stable and welfare enhancing framework during the economic catch-up process.

The results from our empirical estimation lead us to the conclusion that flexible exchange rates affect nominal wage growth negatively. As nominal exchange rates appreciate, nominal wages increases are smaller. In addition, there is some evidence that higher exchange rate uncertainty will lead to a discount on nominal and real wage increases, as uncertainty for the wage bargaining process increases. In contrast, pegging the exchange rate tightly to the euro implied that nominal and real wage increases tend to be higher.

The economic policy conclusion is that the Central and Eastern European economies should adopt a fixed exchange rate regime during the economic catch-up process. The finding is in line with Schnabl (2008) who finds higher growth in countries at the EMU periphery with fixed exchange rate regimes. From this perspective, the benefits of higher growth and welfare in countries with fixed exchange rate regimes can be distributed via higher wages granted to the household sector via the wage bargaining process.

\section{References}

Andersen, T. G., T. Bollerslev, F. X. Diebold, P. Labysl (2003): Modeling and Forecasting Realized Volatility. Econometrica 71, 579--625.

Arellano, M. (1987). Computing Robust Standard Errors for Within-Groups Estimators, Oxford Bulletin of Economics and Statistics 49, 431-434.

Aukrust, O., F. Holte, G. Stoltz (1967): Instilling II fra Utredningsutvalget for Inntektsoppgjörene 1966, Oslo.

Babetskii, I. (2007): Aggregate Wage Flexibility in Selected New EU Member States. CESifo Working Paper 1916. 
Balassa, B. (1964): The Purchasing-Power Parity Doctrine: A Reappraisal. Journal of Political Economy 6, 584-566.

Belke, A., L. Kaas (2004): Exchange Rate Movements and Employment Growth: An OCA Assessment of the CEE Economies. Empirica 31, 247-280.

Belke, A., L. Kaas, R. Setzer (2004): Exchange Rate Volatility and Labor Markets in the CEE Economies. CEPR Discussion Paper 4802.

Belke, A., R. Setzer (2003): Exchange Rate Volatility and Employment Growth: Empirical Evidence from the CEE Economies. CESIfo Working Paper 1056.

Bergstrand, J. H. (1991): Structural Determinants of Real Exchange Rates and National Price Levels: Some Empirical Evidence. The American Economic Review 81, 325-334.

Bollerslev, T. (1986): Generalized Autoregressive Conditional Heteroskedasticity. Journal of Econometrics 31, 307-327.

Choi, I. (2001): Unit Root Tests for Panel Data, Journal of International Money and Finance 20, 249-272.

De Grauwe, P., G. Schnabl (2005): Nominal versus Real Convergence with Respect to EMU Accession - EMU Entry Scenarios for the New Member States. Kyklos 58, 481-499.

De Grauwe, P., G. Schnabl (2008): Exchange Rate Stability, Inflation and Growth in the (South) Eastern and Central Europe. Review of Development Economics 12, 530-549.

European Central Bank (ECB) (2008): The International Role of the Euro.

ECOFIN (2005): The Employment Guidelines (2005-2008).

Edgren, G., K.-O.Faxén , C.-E. Odhner, 1970, Lönbebildning och Samhällsekonomi (Wage Formation and the Economy, in Swedish), Rabén \& Sjögren, Stockholm.

European Foundation for the Improvement of Living and Working Conditions (EIRO) (2008): Working Time Developments - 2007.

European Commission (2007): Ten Years of the European Employment Strategy (EES).

Fidrmuc, J., I. Korhonen (2006): Meta-Analysis of the Business Cycle Correlation between the Euro Area and the CEECs. Journal of Comparative Economics 34, 518-537.

Forslund, A., N. Gottfries, A. Westermark (2006): Real and Nominal Wage Adjustment in Open Economies, CESifo Working Papers 1649.

Friedman, M. (1953): The Case for Flexible Exchange Rates. In Essays of Positive Economics, ed. by Milton Friedman (Chicago: University of Chicago Press). 
Ghosh, A., A.-M. Gulde, H. Wolf (2003): Exchange Rate Regimes: Choices and Consequences (Cambridge, Massachusetts: MIT Press).

Goretti, M. (2008): Wage-Price Setting in New EU Member States, IMF Workings Paper 243.

Gruber, T. (2004): Employment and Labour Market Flexibility in the New EU Member States. Focus on European Economic Integration 1, OeNB, Vienna.

Hagen, J. von, Z. Jizhong (2005): The Choice of an Exchange Rate Regime - An Empirical Analysis for Transition Economies, Economics of Transition 13, 679-703.

Iara, A., I. Traistaru (2004): How Flexible are Wages in EU Accession Countries? Labour Economics 11, 431-450.

Lindbeck, A. (1979): Inflation and Unemployment in Open Economies, Amsterdam, North Holland.

Maddala, G.S., S. Wu (1999): A Comparative Study of Unit Root Tests with Panel Data and a New Simple Test, Oxford Bulletin of Economics and Statistics 61, 631-652.

McKinnon, R., G. Schnabl (2006): China’s Exchange Rate and International Adjustment in Wages, Prices, and Interest Rates: Japan Déjà Vu? CESifo Studies 1720.

Meade, J. (1951): The Theory of International Economic Policy (London: Oxford University Press).

Mundell, R. (1961): A Theory of Optimal Currency Areas. American Economic Review 51, 657665.

Paas, T., R. Eamets, M. Rõõm, J. Masso, R. Selliov, A. Jürgenson (2002): Labour Flexibility and Migration in the EU Eastward Enlargement Context: The Case of the Baltic States, Ezoneplus Working Paper 11.

Samuelson, P. (1964): Theoretical Notes on Trade Problems. Review of Economics and Statistics 64, 145-154.

Schnabl, G. (2008): Exchange Rate Volatility and Growth in Small Open Economies at the EMU Periphery, Economic Systems 32, 70-91.

White, H. (1980): Heteroskedasticity-Consistent Covariance Matrix Estimator and a Direct Test for Heteroskedasticity, Econometrica 48, 817-838. 


\section{CESifo Working Paper Series}

for full list see www.cesifo-group.org/wp

(address: Poschingerstr. 5, 81679 Munich, Germany, office@cesifo.de)

2409 Alexander Kemnitz, Native Welfare Losses from High Skilled Immigration, September 2008

2410 Xavier Vives, Strategic Supply Function Competition with Private Information, September 2008

2411 Fabio Padovano and Roberto Ricciuti, The Political Competition-Economic Performance Puzzle: Evidence from the OECD Countries and the Italian Regions, September 2008

2412 Joan Costa-Font and Mireia Jofre-Bonet, Body Image and Food Disorders: Evidence from a Sample of European Women, September 2008

2413 Thorsten Upmann, Labour Unions - To Unite or to Separate?, October 2008

2414 Sascha O. Becker and Ludger Woessmann, Luther and the Girls: Religious Denomination and the Female Education Gap in $19^{\text {th }}$ Century Prussia, October 2008

2415 Florian Englmaier and Stephen Leider, Contractual and Organizational Structure with Reciprocal Agents, October 2008

2416 Vittorio Daniele and Ugo Marani, Organized Crime and Foreign Direct Investment: The Italian Case, October 2008

2417 Valentina Bosetti, Carlo Carraro, Alessandra Sgobbi and Massimo Tavoni, Modelling Economic Impacts of Alternative International Climate Policy Architectures. A Quantitative and Comparative Assessment of Architectures for Agreement, October 2008

2418 Paul De Grauwe, Animal Spirits and Monetary Policy, October 2008

2419 Guglielmo Maria Caporale, Christophe Rault, Robert Sova and Anamaria Sova, On the Bilateral Trade Effects of Free Trade Agreements between the EU-15 and the CEEC-4 Countries, October 2008

2420 Yin-Wong Cheung and Daniel Friedman, Speculative Attacks: A Laboratory Study in Continuous Time, October 2008

2421 Kamila Fialová and Ondřej Schneider, Labour Market Institutions and their Effect on Labour Market Performance in the New EU Member Countries, October 2008

2422 Alexander Ludwig and Michael Reiter, Sharing Demographic Risk - Who is Afraid of the Baby Bust?, October 2008 
2423 Doina Maria Radulescu and Michael Stimmelmayr, The Welfare Loss from Differential Taxation of Sectors in Germany, October 2008

2424 Nikolaus Wolf, Was Germany ever United? Evidence from Intra- and International Trade 1885 - 1933, October 2008

2425 Bruno S. Frey, David A. Savage and Benno Torgler, Noblesse Oblige? Determinants of Survival in a Life and Death Situation, October 2008

2426 Giovanni Facchini, Peri Silva and Gerald Willmann, The Customs Union Issue: Why do we Observe so few of them?, October 2008

2427 Wido Geis, Silke Uebelmesser and Martin Werding, Why go to France or Germany, if you could as well go to the UK or the US? Selective Features of Immigration to four major OECD Countries, October 2008

2428 Geeta Kingdon and Francis Teal, Teacher Unions, Teacher Pay and Student Performance in India: A Pupil Fixed Effects Approach, October 2008

2429 Andreas Haufler and Marco Runkel, Firms' Financial Choices and Thin Capitalization Rules under Corporate Tax Competition, October 2008

2430 Matz Dahlberg, Heléne Lundqvist and Eva Mörk, Intergovernmental Grants and Bureaucratic Power, October 2008

2431 Alfons J. Weichenrieder and Tina Klautke, Taxes and the Efficiency Costs of Capital Distortions, October 2008

2432 Andreas Knabe and Ronnie Schöb, Minimum Wage Incidence: The Case for Germany, October 2008

2433 Kurt R. Brekke and Odd Rune Straume, Pharmaceutical Patents: Incentives for R\&D or Marketing?, October 2008

2434 Scott Alan Carson, Geography, Insolation, and Institutional Change in $19^{\text {th }}$ Century African-American and White Stature in Southern States, October 2008

2435 Emilia Del Bono and Daniela Vuri, Job Mobility and the Gender Wage Gap in Italy, October 2008

2436 Marco Angrisani, Antonio Guarino, Steffen Huck and Nathan Larson, No-Trade in the Laboratory, October 2008

2437 Josse Delfgaauw and Robert Dur, Managerial Talent, Motivation, and Self-Selection into Public Management, October 2008

2438 Christian Bauer and Wolfgang Buchholz, How Changing Prudence and Risk Aversion Affect Optimal Saving, October 2008 
2439 Erich Battistin, Clara Graziano and Bruno Parigi, Connections and Performance in Bankers' Turnover: Better Wed over the Mixen than over the Moor, October 2008

2440 Erkki Koskela and Panu Poutvaara, Flexible Outsourcing and the Impacts of Labour Taxation in European Welfare States, October 2008

2441 Marcelo Resende, Concentration and Market Size: Lower Bound Estimates for the Brazilian Industry, October 2008

2442 Giandomenico Piluso and Roberto Ricciuti, Fiscal Policy and the Banking System in Italy. Have Taxes, Public Spending and Banks been Procyclical in the Long-Run? October 2008

2443 Bruno S. Frey and Katja Rost, Do Rankings Reflect Research Quality?, October 2008

2444 Guglielmo Maria Caporale, Antoaneta Serguieva and Hao Wu, Financial Contagion: Evolutionary Optimisation of a Multinational Agent-Based Model, October 2008

2445 Valentina Bosetti, Carlo Carraro and Massimo Tavoni, Delayed Participation of Developing Countries to Climate Agreements: Should Action in the EU and US be Postponed?, October 2008

2446 Alexander Kovalenkov and Xavier Vives, Competitive Rational Expectations Equilibria without Apology, November 2008

2447 Thiess Buettner and Fédéric Holm-Hadulla, Cities in Fiscal Equalization, November 2008

2448 Harry H. Kelejian and Ingmar R. Prucha, Specification and Estimation of Spatial Autoregressive Models with Autoregressive and Heteroskedastic Disturbances, November 2008

2449 Jan Bouckaert, Hans Degryse and Thomas Provoost, Enhancing Market Power by Reducing Switching Costs, November 2008

2450 Frank Heinemann, Escaping from a Combination of Liquidity Trap and Credit Crunch, November 2008

2451 Dan Anderberg, Optimal Policy and the Risk Properties of Human Capital Reconsidered, November 2008

2452 Christian Keuschnigg and Evelyn Ribi, Outsourcing, Unemployment and Welfare Policy, November 2008

2453 Bernd Theilen, Market Competition and Lower Tier Incentives, November 2008

2454 Ondřej Schneider, Voting in the European Union - Central Europe's Lost Voice, November 2008 
2455 Oliver Lorz and Gerald Willmann, Enlargement versus Deepening: The Trade-off Facing Economic Unions, November 2008

2456 Alfons J. Weichenrieder and Helen Windischbauer, Thin-Capitalization Rules and Company Responses, Experience from German Legislation, November 2008

2457 Andreas Knabe and Steffen Rätzel, Scarring or Scaring? The Psychological Impact of Past Unemployment and Future Unemployment Risk, November 2008

2458 John Whalley and Sean Walsh, Bringing the Copenhagen Global Climate Change Negotiations to Conclusion, November 2008

2459 Daniel Mejía, The War on Illegal Drugs in Producer and Consumer Countries: A Simple Analytical Framework, November 2008

2460 Carola Frydman, Learning from the Past: Trends in Executive Compensation over the Twentieth Century, November 2008

2461 Wolfgang Ochel, The Political Economy of Two-tier Reforms of Employment Protection in Europe, November 2008

2462 Peter Egger and Doina Maria Radulescu, The Influence of Labor Taxes on the Migration of Skilled Workers, November 2008

2463 Oliver Falck, Stephan Heblich and Stefan Kipar, The Extension of Clusters: Differencein-Differences Evidence from the Bavarian State-Wide Cluster Policy, November 2008

2464 Lei Yang and Keith E. Maskus, Intellectual Property Rights, Technology Transfer and Exports in Developing Countries, November 2008

2465 Claudia M. Buch, The Great Risk Shift? Income Volatility in an International Perspective, November 2008

2466 Walter H. Fisher and Ben J. Heijdra, Growth and the Ageing Joneses, November 2008

2467 Louis Eeckhoudt, Harris Schlesinger and Ilia Tsetlin, Apportioning of Risks via Stochastic Dominance, November 2008

2468 Elin Halvorsen and Thor O. Thoresen, Parents' Desire to Make Equal Inter Vivos Transfers, November 2008

2469 Anna Montén and Marcel Thum, Ageing Municipalities, Gerontocracy and Fiscal Competition, November 2008

2470 Volker Meier and Matthias Wrede, Reducing the Excess Burden of Subsidizing the Stork: Joint Taxation, Individual Taxation, and Family Splitting, November 2008

2471 Gunther Schnabl and Christina Ziegler, Exchange Rate Regime and Wage Determination in Central and Eastern Europe, November 2008 